\title{
Ocena właściwości antyoksydacyjnych liści Ginkgo biloba L. po zakończeniu wegetacji
}

\author{
The evaluation of the antioxidant properties of Ginkgo biloba L. leaves after \\ the end of the growing season
}

\author{
Anna Nowak ${ }^{1 凶}$, Joanna Zielonka-Brzezicka¹, Danuta Pechaiko², Magdalena Tkacz², Adam Klimowicz² \\ 1 Pomorski Uniwersytet Medyczny w Szczecinie, Katedra i Zakład Chemii Kosmetycznej, al. Powstańców Wlkp. 72, 70-111 Szczecin \\ ${ }^{2}$ Pomorski Uniwersytet Medyczny w Szczecinie, Studenckie Koło Naukowe przy Katedrze i Zakładzie Chemii Kosmetycznej i Farmaceutycznej, \\ al. Powstańców Wlkp. 72, 70-111 Szczecin \\ $\triangle$ anowak@pum.edu.pl
}

\begin{abstract}
Introduction: Ginkgo biloba L. is considered to be a valuable plant which exhibits antiradical activity, attributed to the content of polyphenols, terpenoids, vitamins, and other active substances. The leaf extracts are used for therapeutic purposes, commonly in the prevention of lifestyle diseases.

The aim of the study was to evaluate the antioxidant activity of the alcohol extracts of ginkgo biloba dried leaves, fallen from trees, after the end of the growing season, which usually constitute waste material.

Materials and methods: Raw plant material consisted of freshly harvested and dried leaves of ginkgo biloba. The extracts for analysis were prepared using a Soxhlet apparatus, a rotary shaker, as well as an ultrasonic bath. Methanol and ethanol were used as extraction solvents. Antioxidant activity (radical scavenging activity - RSA\%) was determined by the DPPH method, while the total polyphenol content was measured by the Folin-Ciocalteu method. Results: The antioxidant activity of dried ginkgo leaf extracts ranged from $37.69 \pm 1.97$ to $92.85 \pm 0.28 \%$. The highest values
\end{abstract}

were found in $40 \%(\mathrm{v} / \mathrm{v})$ ethanol extracts. Among the $70 \%(\mathrm{v} / \mathrm{v})$ ethanolic extracts, the highest values of RSA were observed in the leaves extracted with a shaker ( $92.37 \pm 0.84 \%)$, whereas using $96 \%(\mathrm{v} / \mathrm{v})$ ethanol as the solvent - extracts were received in the Soxhlet apparatus ( $81.71 \pm 2.10 \%)$. The antioxidant potential of methanol extracts was also high, reaching the value of $89.25 \pm 0.54 \%$ for those obtained by using the shaker. The highest total phenolic content, of about $9.15 \mathrm{mg} / \mathrm{g}$ of material, was observed in samples extracted with $40 \%$ (v/v) ethanol in the Soxhlet apparatus. A positive correlation between the total polyphenol content and antioxidant activity of the analyzed samples was also demonstrated.

Conclusions: Extracts of ginkgo biloba yellow leaves, collected after the end of the growing season, showed a high capability to scavenge free radicals, which suggests the possibility of using this waste material as a valuable source of antioxidants.

Keywords: ginkgo biloba; antioxidants; DPPH method; Folin-Ciocalteu method; polyphenols.

\begin{abstract}
ABSTRAKT
Wstęp: Miłorząb japoński (Ginkgo biloba L.) jest uważany za cenną roślinę wykazującą działanie przeciwrodnikowe. Związane jest to m.in. z zawartością takich substancji aktywnych, jak polifenole, terpenoidy i witaminy. W celach leczniczych wykorzystuje się ekstrakty z liści, które stosowane są m.in. w profilaktyce chorób cywilizacyjnych.

Celem badań było określenie aktywności antyoksydacyjnej wyciągów alkoholowych z suszonych liści miłorzębu japońskiego, opadłych z drzew po zakończonej wegetacji, które najczęściej są materiałem odpadowym.

Materiały i metody: Surowiec roślinny stanowiły świeżo zebrane oraz suszone liście miłorzębu japońskiego. Ekstrakty do analiz przygotowano z wykorzystaniem aparatu Soxhleta, wytrząsarki rotacyjnej oraz łaźni ultradźwiękowej. Jako rozpuszczalnik zastosowano etanol oraz metanol. Zdolność do eliminowania wolnych rodników (radical scavenging activity - RSA) oznaczono metodą z użyciem odczynnika DPPH (2,2-difenylo-1-pikrylohydrazyl), natomiast całkowitą zawartość polifenoli metodą Folina-Ciocalteu'a.
\end{abstract}

Wyniki: Aktywność antyoksydacyjna wyciągów z suchych liści miłorzębu mieściła się w granicach od 37,69 \$1,97 do 92,85 $\pm 0,28 \%$ RSA, przy czym najwyższy wynik uzyskano w grupie ekstraktów w 40\% (v/v) etanolu. Spośród wyciągów w 70\% (v/v) etanolu najwyższymi wartościami RSA\% charakteryzowały się liście ekstrahowane za pomocą wytrząsarki $(92,37 \pm 0,84 \%$ RSA), natomiast w przypadku zastosowania $96 \%$ (v/v) etanolu ekstrakty pochodzące z aparatu Soxhleta $(81,71 \pm 2,10 \%)$. Duże zdolności przeciwutleniające wykazywały również wyciągi metanolowe. Do ich otrzymania wykorzystano wytrząsarkę i uzyskano wynik wynoszący $89,25 \pm 0,54 \%$ RSA. Najwyższą ogólną zawartość polifenoli odnotowano w próbach ekstrahowanych w aparacie Soxhleta (etanol 40\%), w których zawartość wynosiła 9,15 mg/g surowca. Wykazano również dodatnią korelację pomiędzy ogólną zawartością polifenoli a aktywnością antyoksydacyjną wyrażoną w \% RSA analizowanych prób. Wnioski: Wyciągi z żółtych liści miłorzębu japońskiego zebranych po zakończonej wegetacji charakteryzują się dużą zdolnością zmiatania wolnych rodników, co sugeruje możliwość wykorzystania tego materiału odpadowego jako cennego źródła antyoksydantów.

Słowa kluczowe: miłorząb japoński; antyoksydanty; metoda DPPH; metoda Folina-Ciocalteu'a; polifenole. 


\section{WSTEP}

W organizmie ludzkim stale zachodzą procesy metaboliczne, podczas których powstają różne produkty uboczne, w tym zaliczane do reaktywnych form tlenu rodniki. Są to cząsteczki zawierające minimum jeden niesparowany elektron, a co za tym idzie - wykazujące większą reaktywność $[1,2]$. Tworzą się one zarówno w wyniku procesów fizjologicznych, np. wzrostu i różnicowania komórek, jak i patologicznych, takich jak infekcje i reakcje immunologiczne [3, 4]. Organizm człowieka w pewnym stopniu przystosowany jest do ochrony przeciwrodnikowej i utrzymania równowagi tlenowej komórek poprzez różnego rodzaju mechanizmy enzymatyczne i nieenzymatyczne. W niektórych przypadkach mogą się one okazać jednak niewystarczające, wówczas ilość reaktywnych form tlenu przewyższa naturalną zdolność do ich eliminacji. Mówi się wtedy o zjawisku stresu oksydacyjnego, który może prowadzić do uszkodzeń struktur komórkowych, a w konsekwencji do różnych schorzeń. Nadmiar utleniaczy może przyczyniać się do rozwoju m.in.: cukrzycy, miażdżycy tętnic, nowotworów, przedwczesnego starzenia się organizmu $[2,4,5]$.

Linią obrony przed destrukcyjnym działaniem nadmiaru rodników są przeciwutleniacze, będące cząsteczkami o zdolnościach hamujących utlenianie, jednocześnie chroniącymi organizm przed stresem oksydacyjnym [6]. Antyoksydanty działają poprzez różne mechanizmy neutralizacji i wychwytywania wolnych rodników, czego efektem może być ochrona struktur komórkowych. Ze względu na te właściwości przypisuje się im działanie przeciwzapalne, uszczelniające naczynia krwionośne, przeciwnowotworowe i przeciwmutagenne. Może mieć to istotne znaczenie w profilaktyce chorób cywilizacyjnych, a także przedwczesnego starzenia się skóry $[1,7,8]$. W celu zwiększenia skuteczności wykorzystywane jest współdziałanie antyoksydantów o różnych mechanizmach działania oraz o różnym pochodzeniu. Cennym naturalnym źródłem antyoksydantów są rośliny, w tym niektóre krzewy i drzewa, a także znane warzywa, owoce, przyprawy i zioła $[7,8,9,10]$.

Ginkgo biloba L. (miłorząb japoński, chiński, dwudzielny, dwuklapowy) jest drzewem należącym do rodziny miłorząbowatych (Ginkgoaceae). Jest to roślina stosowana w tradycyjnej medycynie chińskiej od tysięcy lat. Miłorząb jest gatunkiem endemicznym i reliktowym, który występuje naturalnie tylko na terenie Chin, ale obecnie można go spotkać w innych regionach świata, gdzie sprowadza się go do celów ozdobnych.

Ze względu na właściwości prozdrowotne jest jedną z częściej wykorzystywanych roślin w profilaktyce chorób neurologicznych, układu krążenia czy hiperglikemii [11, 12].

Miłorząb japoński może mieć wpływ na redukowanie skutków stresu oksydacyjnego [13, 14], co związane jest z dużą zawartością cennych naturalnych antyoksydantów, tj. polifenoli, terpenoidów i witamin. W celach farmakologicznych wykorzystuje się zwykle zielone liście miłorzębu, natomiast coraz częściej autorzy sugerują możliwość wykorzystania liści żółtych, o odmiennej zawartości substancji czynnych. W piśmiennictwie można znaleźć doniesienia o większej zawartości cennych polifenoli w liściach żółtych miłorzębu japońskiego w porównaniu z liśćmi zielonymi $[15,16]$.

Celem badań było określenie aktywności antyoksydacyjnej ekstraktów otrzymanych z suszonych liści miłorzębu japońskiego opadłych z drzew po zakończeniu procesu wegetacji, które najczęściej są materiałem odpadowym.

\section{MATERIAtY I METODY}

Kwas 6-hydroksy-2,5,7,8-tetrametylchromano-2-karboksylowy (troloks), 2,2-difenylo-1-pikrylohydrazyl (DPPH) pochodziły z firmy Sigma Aldrich (Saint Louis, USA); kwas galusowy i odczynnik Folina-Ciocalteu'a z firmy Merck (Darmstadt, Niemcy); węglan sodu z Chempur (Piekary Śląskie, Polska).

Surowiec roślinny, pochodzący z zasobów własnych, stanowiły świeże i suszone liście miłorzębu japońskiego (Ginkgo biloba L.). Liście świeże posłużyły do wyznaczenia przebiegu kinetyki procesu wygaszania rodnika DPPH, natomiast liście suche do dalszych analiz dotyczących oznaczenia właściwości antyoksydacyjnych oraz zawartości polifenoli. Liście suszono w temperaturze pokojowej przez okres 2 tyg. Ekstrakty sporządzano w proporcji $1 \mathrm{~g}$ surowca roślinnego na $20 \mathrm{~cm}^{3}$ rozpuszczalnika. Próbki przygotowano przy użyciu aparatu Soxhleta, wytrząsarki rotacyjnej (czas ekstrakcji - 180 min, częstotliwość rotacji - $400 \mathrm{obr}$./min) oraz łaźni ultradźwiękowej, w przypadku której próbki poddawano działaniu ultradźwięków przez 15, 30 i 60 min. Jako rozpuszczalnik wykorzystano etanol w trzech stężeniach (40\%, 70\% i 96\% v/v) oraz stężony metanol.

Analizę właściwości antyoksydacyjnych przeprowadzono za pomocą nieznacznie zmodyfikowanej metody z użyciem odczynnika DPPH opisanej przez Molyneuxa, Abderrahima i wsp., Ma i wsp., Regulską i Samsonowicza [17, 18, 19, 20]. W przypadku oznaczeń dotyczących DPPH materiałem odniesienia był etanolowy roztwór troloksu. Pomiar absorbancji wykonano przy długości fali równej $517 \mathrm{~nm}$. Krzywą wzorcową wykreślono na podstawie zawartości niezredukowanego DPPH w badanej próbie, która jest odwrotnie proporcjonalna do stężenia antyoksydantu. Dla badanych prób obliczono równoważniki stężeń wzorcowego antyoksydantu - troloksu, jakim odpowiadają badane ekstrakty. Określono również zdolność do eliminacji wolnych rodników (radical scavenging activity - RSA), korzystając ze wzoru:

$$
R S A[\%]=\left(1-\frac{A_{p}}{A_{0}}\right) \cdot 100 \%
$$

gdzie $A_{p}$ oznacza średnią absorbancję próbki badanej, natomiast $A_{o}$ - średnią absorbancję próbki kontrolnej.

Całkowita zawartość polifenoli została oznaczona przy użyciu nieznacznie zmodyfikowanej metody Folina-Ciocalteu'a opisanej przez Tana i wsp. [21]. Wykorzystano tu odwracalną reakcję redukcji molibdenu(VI) do molibdenu(V). Pierwiastek ten wchodzi w skład odczynnika Folina-Ciocalteu’a, który w środowisku zasadowym w obecności polifenoli zmienia barwę na niebieską. Jako odczynnik wzorcowy do oznaczenia stężenia polifenoli w badanych próbkach wykorzystano 
kwas galusowy, którego odpowiednie stężenia dały podstawę do wyznaczenia krzywej kalibracyjnej przy długości fali $750 \mathrm{~nm}$.

Analizę statystyczną wyników przeprowadzono z zastosowaniem programu Statistica 12, wykorzystując jednoczynnikową analizę wariancji ANOVA przy poziomie istotności $\alpha=0,05$. Różnice międzygrupowe oceniano testem Tukeya (n=3). Obliczono również współczynnik korelacji liniowej Pearsona pomiędzy całkowitą zawartością polifenoli a aktywnością antyoksydacyjną liści miłorzębu oznaczoną metodą DPPH.

\section{WYNIKI}

W tabeli 1 przedstawiono wyniki pomiarów aktywności przeciwutleniającej wyciągów z żółtych liści miłorzębu ekstrahowanych etanolem o stężeniu 40\%, 70\% i 96\% (v/v) oraz metanolem, z uwzględnieniem zastosowanego sposobu ekstrakcji. Wyciągi roślinne pozyskano przy użyciu aparatu Soxhleta, wytrząsarki (czas ekstrakcji 180 min) oraz łaźni ultradźwiękowej $(15,30$ i $60 \mathrm{~min})$. Wyniki przedstawiono jako średnie arytmetyczne \pm odchylenie standardowe. Aktywność antyoksydacyjną wyrażono jako \% RSA oraz odpowiadające badanym próbom stężenia troloksu (mg troloksu/g surowca). Zdolności przeciwutleniające wyciągów z suchych liści miłorzębu mieściły się w granicach od 37,69 $\pm 1,97 \%$ do $92,85 \pm 0,28 \%$. Wśród wyciągów sporządzonych poszczególnymi metodami ekstrakcji w 40\% etanolu aktywność antyoksydacyjna RSA kształtowała się na podobnym poziomie i nie odnotowano w tej grupie istotnych różnic. W tym przypadku najwyższe wyniki, nie różniące się znamiennie od innych prób, uzyskano w przypadku ekstraktów otrzymanych z wykorzystaniem aparatu Soxhleta oraz ekstrakcji wspomaganej ultradźwiękami przez $30 \mathrm{~min}$, odpowiednio 92,66 $\pm 0,07 \%$ i 92,85 $\pm 0,28 \%$. Najmniejszą aktywnością antyoksydacyjną charakteryzowały się ekstrakty otrzymane za pomocą ultradźwięków w czasie
60 min - 89,64 $\pm 1,06 \%$. Wyciągi pochodzące z ekstrakcji alkoholem etylowym o stężeniu 70\% również charakteryzowały się dużymi właściwościami przeciwrodnikowymi, jednak w tym przypadku najwyższy istotnie wynik wykazały próby uzyskane przy użyciu wytrząsarki, gdzie aktywność antyoksydacyjna wynosiła 92,37 $\pm 0,84 \%$, a istotnie najniższy przy użyciu aparatu Soxhleta $(69,26 \pm 0,78 \%)$. W grupie ekstraktów otrzymanych z zastosowaniem etanolu o stężeniu 96\% największą zdolność wykazały wyciągi uzyskane przy użyciu aparatu Soxhleta $81,71 \pm 2,10 \%$; wartość ta różniła się istotnie od pozostałych metod ekstrakcji, zaś najmniejszą cechowały się ekstrakty otrzymane za pomocą wytrząsania $(32,44 \pm 2,90 \%)$. Również dużą zdolnością zmiatania wolnych rodników charakteryzowały się wyciągi metanolowe uzyskane przy użyciu aparatu Soxhleta $(88,06 \pm 1,44 \%)$ oraz wytrząsarki $(89,25 \pm 0,54 \%)$. W obu przypadkach wyniki różniły się istotnie od wyciągów otrzymanych z zastosowaniem innych metod ekstrakcji, gdzie najmniejszą aktywność antyoksydacyjną stwierdzono w przypadku prób uzyskanych w łaźni ultradźwiękowej w czasie 15 min - tylko 39,85 $\pm 1,98 \%$ (tab. 1).

W tabeli 2 przedstawiono całkowitą zawartość polifenoli w liściach miłorzębu, która mieściła się w granicach od 9,15 $\pm 0,41$ do 0,62 $\pm 0,08 \mathrm{mg} / g$ surowca. W przypadku wyciągów sporządzonych w 40\% (v/v) etanolu najwięcej polifenoli zawierały wyciągi ekstrahowane za pomocą aparatu Soxhleta $-9,15 \pm 0,41 \mathrm{mg} / \mathrm{g}$ surowca oraz za pomocą wytrząsarki 4,37 $\pm 0,18 \mathrm{mg} / \mathrm{g}$ surowca, co różniło je istotnie od pozostałych wyciągów. Podobne wyniki uzyskano podczas badania ekstraktów metanolowych - ogólna zawartość polifenoli w próbach otrzymanych za pomocą aparatu Soxhleta wynosiła 7,69 $\pm 2,02 \mathrm{mg} / \mathrm{g}$ surowca, natomiast wytrząsarki $-5,09 \pm 0,92 \mathrm{mg} / \mathrm{g}$ surowca. Odmienny wynik wykazały wyciągi uzyskane w 70\% etanolu, gdzie istotnie najwyższą zawartością polifenoli charakteryzowały się pozyskane za pomocą łaźni ultradźwiękowej (30 min), a w przypadku ekstraktów w 96\% etanolu przy

TABELA 1. Właściwości przeciwutleniające ekstraktów uzyskanych z żółtych liści miłorzębu zebranych po zakończeniu wegetacji, oznaczone metodą DPPH. Średnia £odchylenie standardowe

\begin{tabular}{|c|c|c|c|c|c|c|c|c|}
\hline \multirow{3}{*}{$\begin{array}{c}\text { Metoda } \\
\text { ekstrakcji }\end{array}$} & \multicolumn{8}{|c|}{ Rozpuszczalnik } \\
\hline & \multicolumn{2}{|c|}{ etanol $40 \%(v / v)$} & \multicolumn{2}{|c|}{ etanol 70\% (v/v) } & \multicolumn{2}{|c|}{ etanol 96\% (v/v) } & \multicolumn{2}{|c|}{ metanol 99,8\% (v/v) } \\
\hline & $\begin{array}{l}\text { RSA } \\
(\%)\end{array}$ & $\begin{array}{c}\text { RT } \\
\text { (mg troloksu/ } \\
\text { g surowca) }\end{array}$ & $\begin{array}{l}\text { RSA } \\
(\%)\end{array}$ & $\begin{array}{c}\text { RT } \\
\text { (mg troloksu/ } \\
\text { g surowca) }\end{array}$ & $\begin{array}{l}\text { RSA } \\
(\%)\end{array}$ & $\begin{array}{c}\text { RT } \\
\text { (mg troloksu/ } \\
\text { g surowca) }\end{array}$ & $\begin{array}{l}\text { RSA } \\
(\%)\end{array}$ & $\begin{array}{c}\text { RT } \\
\text { (mg troloksu/ } \\
\text { g surowca) }\end{array}$ \\
\hline $\begin{array}{l}\text { Za pomocą } \\
\text { aparatu Soxhleta }\end{array}$ & $92,66 \pm 0,07 \mathrm{a}$ & $2,19 \pm 0,00 \mathrm{a}$ & $69,26 \pm 0,78 \mathrm{~d}$ & $1,55 \pm 0,02 \mathrm{~d}$ & $81,71 \pm 2,10 \mathrm{a}$ & $1,89 \pm 0,06 \mathrm{a}$ & $88,06 \pm 1,44 \mathrm{a}$ & $2,07 \pm 0,04 \mathrm{a}$ \\
\hline $\begin{array}{l}\text { Wspomagana } \\
\text { ultradźwiękami - } \\
30 \text { min }\end{array}$ & $92,85 \pm 0,28 \mathrm{a}$ & $2,20 \pm 0,01 \mathrm{a}$ & $91,02 \pm 0,65 a b$ & $2,15 \pm 0,02 a b$ & $45,39 \pm 2,75 b$ & $0,89 \pm 0,08 b$ & $61,27 \pm 4,49 c$ & $1,33 \pm 0,12 \mathrm{c}$ \\
\hline $\begin{array}{l}\text { Wspomagana } \\
\text { ultradźwiękami - } \\
60 \text { min }\end{array}$ & $89,64 \pm 1,06 \mathrm{a}$ & $2,11 \pm 0,03 \mathrm{a}$ & $90,11 \pm 0,44$ bc & $2,12 \pm 0,01 b c$ & $50,09 \pm 1,89 b$ & $1,02 \pm 0,05 b$ & $68,40 \pm 2,83 b$ & $1,53 \pm 0,08 b$ \\
\hline $\begin{array}{l}\text { Wytrząsanie - } \\
180 \text { min }\end{array}$ & $91,74 \pm 0,92 \mathrm{a}$ & $2,17 \pm 0,03 a$ & $92,37 \pm 0,84 \mathrm{a}$ & $2,18 \pm 0,02 \mathrm{a}$ & $32,44 \pm 2,90 \mathrm{c}$ & $0,54 \pm 0,08 c$ & $89,25 \pm 0,54 \mathrm{a}$ & $2,10 \pm 0,01 \mathrm{a}$ \\
\hline
\end{tabular}

RSA - aktywność antyoksydacyjna badanych ekstraktów; RT - równoważnik stężenia troloksu, któremu odpowiadają badane próby. Wartości średnie oznaczone różnymi literami różnią się istotnie statystycznie w obrębie metody ekstrakcji. Poziom istotności: $\alpha=0,05 ; n=3$. 
TABELA 2. Ogólna zawartość polifenoli w $\mathrm{mg} / \mathrm{g}$ surowca (średnia arytmetyczna £odchylenie standardowe) w żółtych liściach miłorzębu po zakończeniu wegetacji

\begin{tabular}{|c|c|c|c|c|}
\hline \multirow[b]{2}{*}{ Metoda ekstrakcji } & \multicolumn{4}{|c|}{ Rozpuszczalnik } \\
\hline & $\begin{array}{c}\text { etanol } \\
40 \%(v / v)\end{array}$ & $\begin{array}{c}\text { etanol } \\
70 \%(v / v)\end{array}$ & $\begin{array}{c}\text { etanol } \\
96 \%(v / v)\end{array}$ & $\begin{array}{c}\text { metanol } \\
99,8 \%(v / v)\end{array}$ \\
\hline Za pomocą aparatu Soxhleta & $9,15 \pm 0,41 \mathrm{a}$ & $2,63 \pm 0,01 b$ & $4,66 \pm 0,05 \mathrm{a}$ & $7,69 \pm 2,02 \mathrm{a}$ \\
\hline Wspomagana ultradźwiękami - 15 min & $3,92 \pm 0,41 b$ & $4,20 \pm 0,94 b$ & $0,94 \pm 0,13 c$ & $0,62 \pm 0,08 b$ \\
\hline Wspomagana ultradźwiękami - 30 min & $4,62 \pm 0,17 b$ & $7,91 \pm 0,75 \mathrm{a}$ & $1,68 \pm 0,41 b c$ & $1,83 \pm 0,18 b$ \\
\hline Wspomagana ultradźwiękami - 60 min & $8,70 \pm 0,30 \mathrm{a}$ & $5,71 \pm 2,56 a b$ & $2,11 \pm 0,39 b$ & $2,00 \pm 0,04 b$ \\
\hline Wytrząsanie - 180 min & $4,37 \pm 0,18 b$ & $3,82 \pm 0,43 b$ & $0,92 \pm 0,48 c$ & $5,09 \pm 0,92 a$ \\
\hline
\end{tabular}

Wartości średnie oznaczone różnymi literami różnią się istotnie statystycznie w obrębie metody ekstrakcji. Poziom istotności: $\alpha=0,05 ; n=3$.

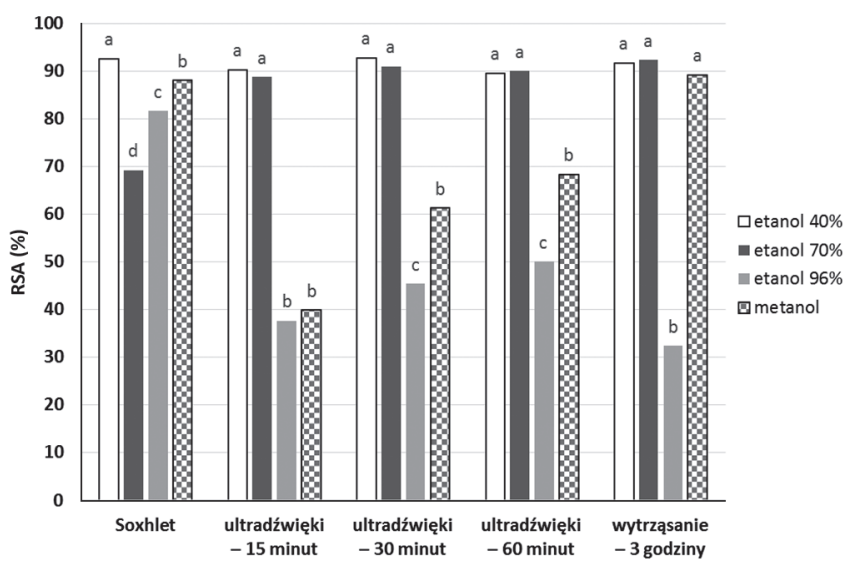

Poziom istotności: $\alpha=0,05 ; n=3$

RYCINA 1. Porównanie średniej aktywności antyoksydacyjnej ekstraktów (RSA) z wykorzystaniem etanolu $40 \%, 70 \%$ i $96 \%$ oraz metanolowego uzyskanych z suchych liści miłorzębu japońskiego

Ultradźwięki $60 \mathrm{~min}$

60

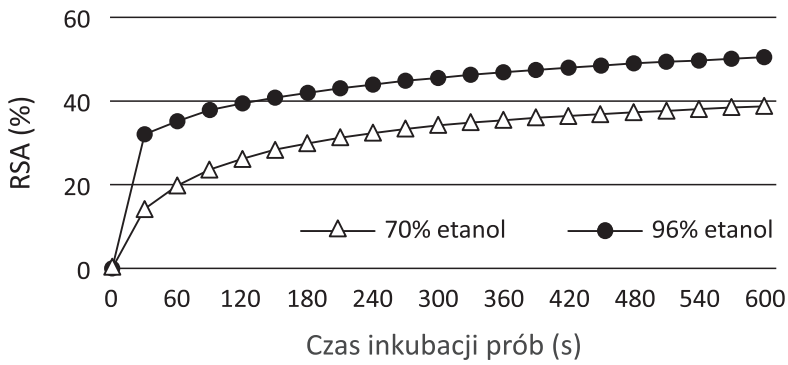

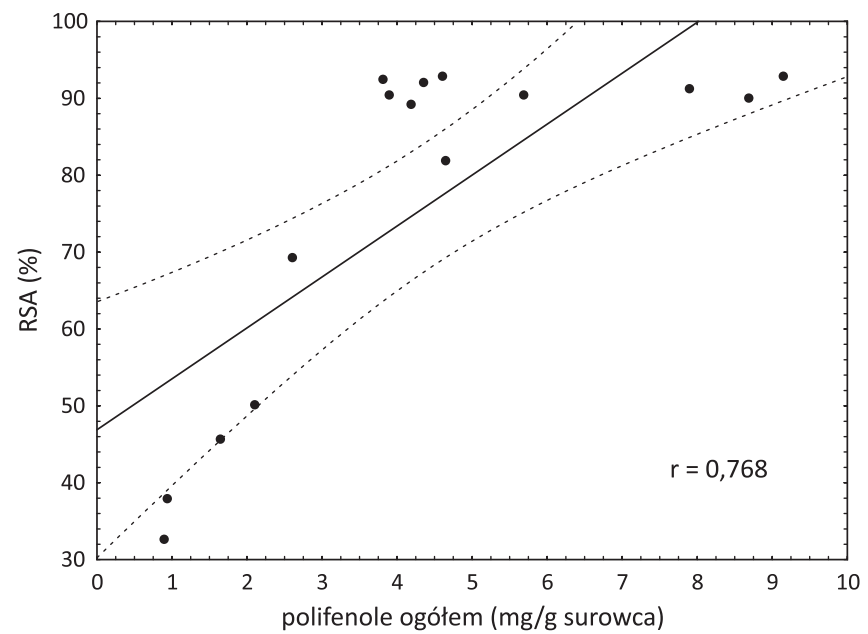

RYCINA 2. Korelacja pomiędzy całkowitą zawartością polifenoli a aktywnością antyoksydacyjną ekstraktów etanolowych (RSA) z miłorzębu japońskiego

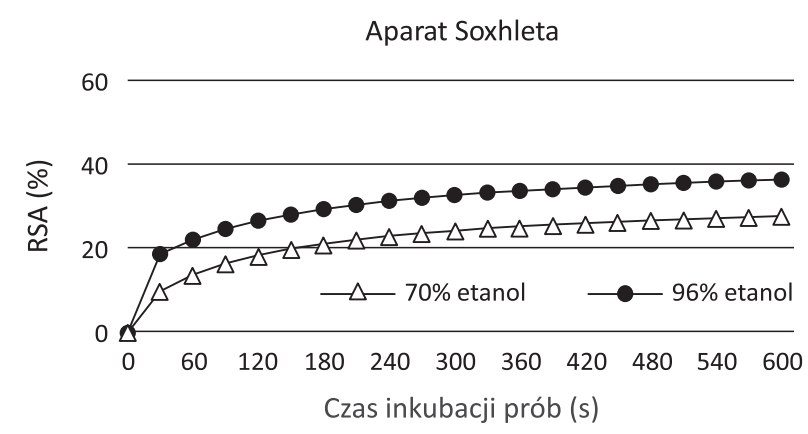

RYCINA 3. Kinetyka zmiany aktywności oksydacyjnej ekstraktów etanolowych (RSA) zielonych liściach miłorzębu japońskiego uzyskanych przy użyciu ultradźwięków oraz aparatu Soxhleta i oznaczonej metodą DPPH w zależności od czasu inkubacji

użyciu aparatu Soxhleta - 4,66 $\pm 0,05 \mathrm{mg} / \mathrm{g}$ surowca. Wyciągami o najmniejszej zawartości polifenoli były próby metanolowe, które ekstrahowane były przy użyciu ultradźwięków (15 min) - 0,62 $\pm 0,08 \mathrm{mg} / \mathrm{g}$ surowca, a w przypadku zastosowania $96 \%$ etanolu - uzyskane za pomocą wytrząsarki (0,92 $\pm 0,48 \mathrm{mg} / \mathrm{g}$ surowca).

Porównanie aktywności antyoksydacyjnej badanych ekstraktów ze względu na rodzaj rozpuszczalnika przedstawiono na rycinie 1. Wyciągi etanolowe o stężeniu rozpuszczalnika 40\% i 70\% charakteryzowały się istotnie wyższą aktywnością antyoksydacyjną w porównaniu z pozostałymi próbami. Najmniejsze badane właściwości wykazały próby etanolowe 96\% (z wyłączeniem wyciągów uzyskanych za pomocą aparatu Soxhleta).
Na rycinie 2 przedstawiono korelację pomiędzy ogólną zawartością polifenoli a całkowitą aktywnością antyoksydacyjną mierzoną w przypadku wyciągów etanolowych uzyskanych wszystkimi przeprowadzonymi metodami ekstrakcji. Wykazano istotną zależność pomiędzy badanymi parametrami; współczynnik korelacji Spearmana wynosił $r=0,768(\mathrm{p}<0,001)$.

Na rycinie 3 przedstawiono przykładowy przebieg kinetyki procesu wygaszania rodnika DPPH w wyciągach ze świeżych liści w czasie inkubacji prób wynoszącym do $10 \mathrm{~min}$, dla ekstraktów uzyskanych przy użyciu aparatu Soxhleta oraz ultradźwięków. Stwierdzono, że czas ustalania równowagi przebiegu reakcji w przypadku wyciągów w 70\% etanolu jest krótszy niż w 96\% etanolu. 


\section{DYSKUSJA}

W badaniach własnych podjęto próbę oznaczenia właściwości antyoksydacyjnych suchych liści miłorzębu japońskiego opadłych z drzew po zakończonej wegetacji. Celem badań była ocena możliwości ich dalszego wykorzystania w przemyśle kosmetycznym i farmaceutycznym jako cennego surowca antyoksydacyjnego. Kobus-Cisowska i wsp. podali, iż właściwości lecznicze liści miłorzębu japońskiego po zakończonej wegetacji nie zostały do końca poznane w porównaniu z liśćmi zielonymi, które są materiałem często wykorzystywanym w przemyśle farmaceutycznym. Autorzy sugerują również, że żółte liście miłorzębu zawierają znacznie większą zawartość polifenoli niż liście zielone, czego konsekwencją jest ich większa zdolność zmiatania wolnych rodników [15]. Sati i wsp. oraz Kobus i wsp. stwierdzili, że właściwości antyoksydacyjne liści miłorzębu ze zbioru jesiennego są znacznie wyższe niż liści ze zbiorów wiosennych i letnich. Podczas żółknięcia liści następują zmiany struktury polifenoli oraz reakcje polimeryzacji, przez co surowiec ten charakteryzuje się znacznie większą ilością substancji aktywnych. Wysuszenie liści następujące po zakończeniu wegetacji usprawnia ich macerację, ułatwia zwilżalność i zwiększa podatność na wnikanie rozpuszczalników podczas przygotowania prób do badań [14, 15, 22]. Duża kumulacja cennych składników w liściach żółtych spowodowana jest prawdopodobnie warunkami stresowymi roślin związanymi z obniżoną temperaturą otoczenia [14].

W doświadczeniu własnym oznaczono aktywność przeciwutleniającą żółtych liści miłorzębu z wykorzystaniem metody z użyciem odczynnika DPPH. Analizując przeprowadzone badania, można stwierdzić, że żółte liście miłorzębu japońskiego, które zakończyły wegetację, charakteryzują się dużą zdolnością zmiatania wolnych rodników, co potwierdzają wyniki zamieszczone w tabeli 1. Na taką ich zdolność wskazują również badania innych autorów z wykorzystaniem liści miłorzębu [13, 14, 15, 23, 24], a także badania przeprowadzone na liściach innych roślin, w tym np. winorośli właściwej [25], aronii czarnej [26], akki sellowej [27], bielunia surmikwiatu [28] czy jeżyny europejskiej [29].

W przeprowadzonych badaniach wykazano, iż metoda ekstrakcji ma istotny wpływ na zdolność zmiatania wolnych rodników otrzymanego wyciągu z surowca roślinnego (tab. 1; ryc. 1). Aktywność antyoksydacyjna suchych liści miłorzębu mieściła się w granicach 37,69-92,85\% RSA, przy czym w grupie ekstraktów w 40\% etanolu, w przypadku wszystkich metod ich pozyskania, utrzymywała się na wysokim poziomie - 89,64-92,85\% RSA. W grupie wyciągów w 70\% etanolu najwyższymi wartościami RSA charakteryzowały się liście ekstrahowane za pomocą wytrząsarki $(92,37 \%)$, natomiast przy zastosowaniu 96\% etanolu - ekstrakty pochodzące z aparatu Soxhleta $(81,71 \%)$. Wysokie wyniki, dochodzące nawet do 89,25\%, uzyskano również dla wyciągów metanolowych. Wartości te wskazują na dość rozbieżną aktywność antyoksydacyjną liści miłorzębu, która zmienia się w zależności od stężenia i rodzaju rozpuszczalnika. W większości przypadków znacznie wyższe zdolności antyoksydacyjne wykazały ekstrakty w 40\% i 70\% etanolu i metanolowe w porównaniu z ekstraktami w 96\% etanolu (ryc. 1). Na dużą zdolność przeciwutleniającą wyciągów z liści miłorzębu z zastosowaniem etanolu jako rozpuszczalnika wskazują również Stefanovits-Banyai i wsp. oraz Zahradnikowa i wsp. [30, 31]. Natomiast Boonkaew i Camper oraz Sati i wsp. zaobserwowali dużą aktywność antyoksydacyjną, ekstrahując liście miłorzębu w metanolu, w porównaniu z innymi rozpuszczalnikami - etanolem, wodą czy acetonem [14, 32]. Istotny wpływ na oceniane właściwości ma również sposób ekstrakcji roślin, co wykazano w badaniach własnych, stosując bowiem aparat Soxhleta i wytrząsarkę, uzyskano wyniki niejednorodne (tab. 1). Peres i wsp. wskazują także na rozbieżność wyników w oznaczaniu zawartości substancji przeciwutleniających przy ekstrakcji roślin z rodziny pieprzowatych z wykorzystaniem aparatu Soxhleta oraz łaźni ultradźwiękowej. Według ich oceny zawartość witaminy E, będącej cennym przeciwutleniaczem, była zróżnicowana w zależności od użytej metody pozyskania wyciągów [33]. Natomiast Bimakr i wsp. badając beninkazę szorstką, uzyskali większe właściwości antyutleniające w próbach otrzymanych za pomocą łaźni ultradźwiękowej w porównaniu z aparatem Soxhleta [34].

W doświadczeniu własnym stwierdzono występowanie polifenoli w liściach miłorzębu japońskiego. Uzyskane wyniki były dość rozbieżne w zależności zarówno od użytego rozpuszczalnika, jak i sposobu uzyskania ekstraktów (tab. 2). Najwyższą ich ogólną zawartość, wynoszącą 9,15 mg/g surowca, odnotowano w próbach ekstrahowanych w aparacie Soxhleta (40\% etanol). Kobus-Cisowska i wsp. wskazują na rozbieżność wyników dotyczących zawartości wybranych związków fenolowych w liściach zielonych i żółtych miłorzębu. Autorzy wykorzystując różne rozpuszczalniki, sporządzili z badanego surowca wyciągi wodne, wodno-acetonowe oraz etanolowe, w przypadku których dużą zawartością związków polifenolowych charakteryzowały się ekstrakty acetonowo-wodne, uzyskane zarówno z liści żółtych, jak i zielonych [15]. Polifenole są cennymi składnikami roślinnymi, które mają wpływ m.in. na proces zmiatania wolnych rodników, co wyraża się dodatnią korelacją pomiędzy ich zawartością a właściwościami antyoksydacyjnymi liści miłorzębu [14, 23, 35]. Potwierdzają to badania własne, w których stwierdzono dodatnią korelację pomiędzy ogólną zawartością polifenoli a ogólną aktywnością antyoksydacyjną RSA na poziomie $r=0,768$ (ryc. 2).

W przeprowadzonych oznaczeniach zbadano także kinetykę procesu wygaszania rodnika DPPH przez ekstrakty ze świeżych liści uzyskane z użyciem aparatu Soxhleta oraz wytrząsarki. Stwierdzono, iż RSA utrzymuje się na stałym poziomie w 10. min oznaczenia, a wynik dla ekstraktów w 70\% etanolu jest niższy niż w przypadku użycia etanolu 96\% (ryc. 3). Mogło to mieć przełożenie na późniejsze wyniki, bowiem aktywność antyoksydacyjna ekstraktów w 70\% etanolu z żółtych liści miłorzębu była w większości przypadków wyższa w porównaniu z ekstraktami sporządzonymi w 96\% etanolu. Kinetykę wygaszania rodnika DPPH badali również inni autorzy, m.in. Kołodziej i Drożdzal, którzy ustalali czas reakcji w ciągu 12 min dla kwiatów oraz owoców bzu czarnego [36], a także Malinowska, 
która zaprezentowała kinetykę ocenianą podczas 10 min dla takich roślin, jak: bez czarny, lipa drobnolistna, borówka czarna, wąkrota azjatycka. Autorka zaobserwowała również rozkład rodnika DPPH w pierwszych minutach od zainicjowania reakcji z wyciągami roślinnymi [37]. Wykres przedstawiający kinetykę rozkładu rodnika DPPH pozwala porównać aktywność antyoksydacyjną dla różnych ekstraktów roślinnych zmieniającą się podczas inkubacji oraz umożliwia dostosowanie odpowiedniego jej czasu koniecznego dla wykonania oznaczeń zdolności zmiatania wolnych rodników.

\section{WNIOSKI}

1. Liście miłorzębu po skończonej wegetacji charakteryzowały się dużą zdolnością antyoksydacyjną, co stwierdzono, badając zarówno próby ekstrahowane za pomocą aparatu Soxhleta, ultradźwięków, jak i wytrząsarki rotacyjnej.

2. W większości przypadków znacznie wyższą aktywnością przeciwrodnikową charakteryzował się badany surowiec roślinny ekstrahowany w etanolu 40\% i 70\% oraz metanolu w porównaniu z ekstraktami, w których rozpuszczalnik stanowił $96 \%$ etanol.

3. Wykazano istotną zależność pomiędzy ogólną zawartością polifenoli a aktywnością antyoksydacyjną wyrażoną w \% RSA analizowanych prób.

4. Z ekologicznego punktu widzenia duża zdolność do zmiatania wolnych rodników ekstraktów z żółtych liści miłorzębu japońskiego po zakończonej wegetacji sugeruje możliwość wykorzystania ich jako cennego źródła antyoksydantów, np. w przemyśle farmaceutycznym czy kosmetycznym.

\section{PIŚMIENNICTWO}

1. Miller E, Malinowska K, Gałęcka E, Mrowicka M, Kędziora J. Rola flawonoidów jako przeciwutleniaczy w organizmie człowieka. Pol Merkur Lekarski 2008;24(144):556-60.

2. Prior RL. Oxygen radical absorbance capacity (ORAC): New horizons in relating dietary antioxidants/bioactives and health benefits. J Funct Foods 2015;18:797-810. doi: 10.1016/j.jff.2014.12.018.

3. Kulbacka J, Saczko J, Chwiłkowska A. Stres oksydacyjny w procesach uszkodzenia komórek. Pol Merkur Lekarski 2009;27(157):44-7.

4. Rezin GT, Andreazza AC. Oxidative damage and its treatment impact. In: Yildiz A, Ruiz P, Nemeroff C, editors. The bipolar book: history, neurobiology, and treatment. Oxford: Oxford University Press; 2015. p. 83-92.

5. Valko M, Jomova K, Rhodes CJ, Kuča K, Musilek K. Redox- and non-redoxmetal-induced formation of free radicals and their role in human disease. Arch Toxicol 2016;90(1):1-37. doi: 10.1007/s00204-015-1579-5.

6. Vinardell MP, Mitjans M. Nanocarriers for delivery of antioxidants on the skin. Cosmetics 2015;2(4):342-54. doi:10.3390/cosmetics2040342.

7. Nowak A, Zielonka J, Turek M, Klimowicz A. Wpływ przeciwutleniaczy zawartych w owocach na proces fotostarzenia się skóry. Post Fitoter 2014;2:94-9.

8. Gryszczyńska B, Iskra M. Współdziałanie antyoksydantów egzogennych i endogennych w organizmie człowieka. Now Lek 2008;77(1):50-5.

9. Embuscado ME. Spices and herbs: Natural sources of antioxidants - a mini review. J Funct Foods 2015;18:811-9. doi: 10.1016/j.jff.2015.03.005.

10. Kałędkiewicz E, Lange E. Znaczenie wybranych związków pochodzenia roślinnego w diecie zapobiegającej chorobom nowotworowym. Post Fitoter 2013;1:42-7.
11. Rojas C, Rojas-Castañeda J, Ruiz-Sánchez E, Montes P, Rojas P. Antioxidant properties of Ginkgo biloba leaf extract (EGb 761) in animal models of Alzheimer's and Parkinson's diseases. Curr Top Nutraceutical Res 2015;13(3):105-20.

12. Greń A. Aktywność antyoksydacyjna preparatów z morwy białej, fasoli zwykłej oraz miłorzębu japońskiego w cukrzycy generowanej podaniem streptozotocyny. Post Fitoter 2012;4:220-5.

13. Pereira E, Barros L, Ferreira I. Chemical characterization of Ginkgo biloba L. and antioxidant properties of its extracts and dietary supplements. Ind Crop Prod 2013;51:244-8. doi: 10.1016/j.indcrop.2013.09.011.

14. Sati P, Pandey A, Rawat S, Rani A. Phytochemical and antioxidants in leaf extracts of Ginkgo biloba with reference to location, seasonal variation and solvent system. J Pharm Res 2013;7(9):804-9. doi: 10.1016/j. jopr.2013.09.001.

15. Kobus-Cisowska J, Flaczyk E, Siger A, Kmiecik D. Wpływ warunków ekstrakcji na wydajność i skład wybranych ekstraktów z liści zielonych i żółtych miłorzębu dwuklapowego. Nauka Przyroda Technologie 2015;9(1): 2-15. doi: 10.17306/J.NPT.2015.1.9.

16. Kobus-Cisowska J, Flaczyk E, Rudzińska M, Kmiecik D. Antioxidant properties of extracts from Ginkgo biloba leaves in meatballs. Meat Sci 2014;97(2):174-80. doi: 10.1016/j.meatsci.2014.01.011.

17. Molyneux $P$. The use of stable free radical diphenylpicrylhydrazyl (DPPH) for estimating antioxidant activity. Songklanakarin J Sci Technol 2004;26(2):211-9.

18. Abderrahim F, Arribas SM, Gonzalez MC, Condezo-Hoyos L. Rapid highthroughput assay to assess scavenging capacity index using DPPH. Food Chem 2013;141(2):788-94. doi: 10.1016/j.foodchem.2013.04.055.

19. Ma Z, Cui F, Gao X, Zhang J, Zheng L, Jia L. Purification, characterization, antioxidant activity and anti-aging of exopolysaccharides by Flammulina velutipes SF-06. Antonie Van Leeuwenhoek 2015;107(1):73-82. doi: 10.1007/s10482-014-0305-2.

20. Regulska E, Samsonowicz M. Ekstrakty ziołowe w aspekcie zawartości związków polifenolowych i aktywności przeciwutleniającej. In: Tarko T, Duda-Chodak A, Witczak M, Najgebauer-Lejko D, editors. Właściwości produktów i surowców żywnościowych. Wybrane zagadnienia. Kraków: Polskie Towarzystwo Technologów Żywności; 2014. p. 227-37.

21. Tan YS, Baskaran A, Nallathamby N, Chua KH, Kuppusamy UR, Sabaratnam $\mathrm{V}$. Influence of customized cooking methods on the phenolic contents and antioxidant activities of selected species of oyster mushrooms (Pleurotus spp.). J Food Sci Technol 2015;52(5):3058-64. doi: 10.1007/ s13197-014-1332-8.

22. Kobus J, Flarczyk E, Siger A, Nogala-Kałucka M, Korczak J, Peeg RB. Phenolic compounds and antioxidant activity of extracts of Ginkgo leaves. Eur J Lipid Sci Technol 2009;111(11):1150-60. doi: 10.1002/ejlt.200800299.

23. Koczka N, Móczár Z, Stefanovits-Bányai É, Ombódi A. Differences in antioxidant properties of ginkgo leaves collected from male and trees. Acta Pharm 2015;65(1):99-104. doi: 10.1515/acph-2015-0001.

24. Shi JY, Zou XB, Zhao JW, Mel H, Wang KL, Wang X, et al. Determination of total flavonoids content in fresh Ginkgo biloba leaf with different colors using near infrared spectroscopy. Spectrochim Acta A Mol Biomol Spectrosc 2012;94:271-6. doi: 10.1016/j.saa.2012.03.078.

25. Csepregi K, Susanne N, Schrener M, Hideg E. Comparative evaluation of total antioxidant capacities of plant polyphenols. Molecules 2016;21(2):208. doi: 10.3390/molecules21020208.

26. Thi ND, Hwang ES. Bioactive compound contents and antioxidant activity in aronia (Aronia melanocarpa) leaves collected at different growth stages. Prev Nutr Food Sci 2014;19(3):204-12. doi: 10.3746/pnf.2014.19.3.204.

27. Beyhan Ö, Elmastaş M, Gedikli F. Total phenolic compounds and antioxidant capacity of leaf, dry fruit and fresh fruit of feijoa (Acca sellowiana, Myrtaceae). J Med Plant Res 2010;4(11):1065-72. doi: 10.5897/JMPR10.008.

28. Alabri TH, Al Musalami AH, Hossain MA, Weli AM, Al-Riyami Q. Comparative study of phytochemical screening, antioxidant and antimicrobial capacities of fresh and dry leaves crude plant extracts of Datura metel L. J King Saud Univ Sci 2014;26(3):237-43. doi: 10.1016/j.jksus.2013.07.002.

29. Asnaashari M, Tajik R, Khodaparast MH. Antioxidant activity of raspberry (Rubus fruticosus) leaves extract and its effect on oxidative stability of sunflower oil. J Food Sci Technol 2015;52(8):5180-7. doi: 10.1007/ s13197-014-1564-7.

30. Stefanovits-Banyai E, Szentmihalyi K, Hegedus A, Koczka N, Vali L, Taba G, et al. Metal ion and antioxidant alterations in leaves between different seeds of Ginkgo biloba L. Life Sci 2006;78:1049. 
31. Zahradnikowa L, Schmidt S, Sekretar S, Janac L. Determination of the antioxidant activity of Ginkgo biloba leaves extract. J Food Nutr Res 2007;46(1):15-9.

32. Boonkaew T, Camper ND. Biological activities of Gingko biloba extracts. Phytomedicine 2005;12(4):318-23. doi: 10.1016/j.phymed.2003.06.008.

33. Peres VF, Saffia J, Melecchi MI, Abadc FC, de Assis Jacques R, Martinez MM, et al. Comparison of Soxhlet, ultrasound-assisted and pressurized liquid extraction of terpenes, fatty acids and vitamin E from Piper gaudichaudianum Kunth. J Chromatogr A 2006;1105(1-2):115-8. doi: 10.1016/j. chroma.2005.07.113.

34. Bimakr M, Rahman RA, Taip FS, Adzahan NM, Sarker ZI, Ganjloo A. Optimization of ultrasound-assisted extraction of crude oil from winter melon (Benincasa hispida) seed using response surface methodology and evaluation of its antioxidant activity, total phenolic content and fatty acid composition. Molecules 2012;17(10):11748-62. doi: 10.3390/ molecules171011748.

35. Aoshima H, Hirata S, Ayabe S. Antioxidative and anti-hydrogen peroxide activities of various herbal teas. Food Chem 2007;103(2):617-22. doi: 10.1016/j.foodchem.2006.08.032.

36. Kołodziej B, Drożdzal K. Właściwości przeciwutleniające kwiatów i owoców bzu czarnego pozyskiwanego ze stanu naturalnego. Żywn Nauka Technol Jakość 2011;4(77):36-44.

37. Malinowska P. Evaluation of antioxidant activity of cosmetics plant extracts using DPPH radical. Pol J Cosmetol 2013;16(1):69-73. 